ПАРАДИГМА ОЦІНКИ ЕФЕКТИВНОСТІ ІНВЕСТИЦІЙ В ЕКОНОМІЦІ КРАЇНИ PARADIGM FOR ESTIMATING EFFECTIVENESS OF INVESTMENTS IN UKRAINE'S ECONOMY

Удк 36:330.342.3 (477) 656.2

DOI: https://doi.org/10.32843/infrastruct54-7

\section{Лінтур I.B.}

к.е.н., доцент кафедри економіки та фрінансів

Мукачівський державний університет Петричко М.M.

к.е.н., доцент кафредри економіки та фрінансів

Мукачівський державний університет Гладинець Н.ю.

к.е.н., доцент кафедри економіки та фрінансів

Мукачівський державний університет

\section{Lintur Inna}

Mukachevo State University

Petrichko Maria

Mukachevo State University

Gladinets Natalia

Mukachevo State University у статті розглянуто сучасні умови процесу розроблення та прийняття рішень про інвестування. Охарактеризовано різні методи оцінки ефективності інвестицій. Досліджено та обгрунтовано актуальність використання квантово-економічного аналізу як одного з найновіших методів аналізу інвестиційних проєктів. Зокрема, зазначено, що відмінність КЕА від використовуваних у даний момент концепцій у тому, що ці методи засновані на аналізі документів бухгалтерського обліку, прогнозі показників, застосуванні до них аудиторського аналізу i розрахунку різних орінансових коефріцієнтів. Однак фрінансовим розрахункам повинен передувати аналіз, що виявляє і відсіває апріорі неефективні та збиткові проєкти. Досліджено зарубіжний досвід проведення оцінки ефрективності інвестицій, на основі вивчення якого сорормовано висновок, що оцінка інвестиційних проєктів повинна грунтуватися на економічних, соціальних і екологічних умовах, вибраних і згрупованих з урахуванням цілей інвестування. Під час оцінки інвестиційних проєктів окремими критеріями дуже важко порівняти проєкти та оцінити їх, тому різні критерії (економічні, фрінансові, соціальні, екологічні тощо) слід поєднувати в одне узагальнене значення. Ключові слова: інвестування, інвестиційний проєкт, методи оцінки інвестицій, критерії оцінки інвестиційного проєкту, зарубіжний досвід інвестування.

В статье рассмотрены современные условия процесса разработки и принятия реше- ний об инвестировании. Охарактеризованы различные методы оценки эффрективности инвестиций. Исследована и обоснована актуальность использования квантово-экономического анализа как одного из новейших методов анализа инвестиционных проектов. В частности, указано, что отличие КЭА от используемых в данный момент концепций в том, что эти методы основаны на анализе документов бухгалтерского учета, прогнозе показателей, применении к ним аудиторского анализа и расчета различных фринансовых коэфффициентов. Однако фринансовым расчетам должен предшествовать анализ, выявляющий и отсеивающий априори неэфроективные и убыточные проекты. Исследован зарубежный опыт проведения оценки эфрфективности инвестиций, на основе изучения которого сорормирован вывод, что оценка инвестиционных проектов должна основываться на экономических, социальных и экологических условиях, избранных и сгруппированных с учетом целей инвестирования. При оценке инвестиционных проектов по отдельным критериям очень трудно сравнить проекты и оценить их, поэтому различные критерии (экономические, фринансовые, социальные, экологические и т. п.) следует объединять в одно обобщенное значение.

Ключевые слова: инвестирование, инвестиционный проект, методы оценки инвестиций, критерии оценки инвестиционного проекта, зарубежный опыт инвестирования.

The article considers the current conditions of the process of development and decision-making on investment. Different methods of investment efficiency assessment are described. The relevance of the use of quantum economic analysis as one of the newest methods of analysis of investment projects is studied and substantiated. In particular, it is noted that the difference between KEA and currently used concepts is that these methods are based on the analysis of accounting documents, forecast indicators, application of audit analysis and calculation of various financial ratios. However, financial calculations must be preceded by an analysis that identifies and eliminates a priori inefficient and unprofitable projects. Determining the economic efficiency of investment projects is the most important and difficult stage of pre-investment research. The timing of the return on investment depends on how objectively and comprehensively this assessment has been carried out and, consequently, on the correct course of further action on a particular project. In turn, objectivity and comprehensiveness provide modern methods of evaluating the effectiveness of investment projects. The methods considered by us are quite accurate, because based on simple calculations, they allow you to quickly assess the economic efficiency of investment projects, they can be used to address issues such as project profitability; determine the benefits of different versions of the project; find out how one project is more effective than another. The foreign experience of investment efficiency assessment is studied. Based on the study of which, it was concluded that the evaluation of investment projects should be based on economic, social and environmental conditions, selected and grouped taking into account the investment objectives. When evaluating investment projects by individual criteria, it is very difficult to compare projects and evaluate them. Therefore, different criteria (economic, financial, social, environmental, etc.), and they should be combined into one generalized meaning.

Key words: investment, investment project, investment evaluation methods, investment project evaluation criteria, foreign investment experience.

Постановка проблеми. У сучасному світі на етапі активного розвитку технологій, науково-технічного та інноваційного прогресу гострою проблемою $€$ ефрективне вкладення капіталу з метою його збільшення, тобто інвестування. Економічна природа інвестицій зумовлена закономірностями процесу відтворення і полягає у використанні частини додаткового суспільного продукту для збільшення кількості й якості всіх елементів системи продуктивних сил суспільства.

Аналіз останніх досліджень і публікацій. Питанням оцінки інвестиційних проєктів, інвес- тиційної привабливості та ефективності інвестицій протягом тривалого періоду часу присвячено чималу кількість наукових праць українських та закордонних дослідників. Проведене дослідження проводилося на основі наукових доробків А.А. Пересади [1], В.Л. Гераймовича [2], В.П. Ніколаєва [4], О.С. Бєлоусова [5], Г.О. Мазура [6], Ю.М. Коваленко [7], І.Г. Лукманової [8], А.М. Немчина [8] та ін.

Постановка завдання. Метою дослідження $€$ аналіз методів оцінки есрективності інвестицій в економіці країни, вивчення зарубіжного досвіду з 
метою фрормування єдиного концепту оцінки інвестиційний проєктів.

Виклад основного матеріалу дослідження. Сучасні умови процесу розроблення та прийняття інвестиційних рішень вимагають від осіб, що їх приймають, постійного усвідомлення того, що прийняте інвестиційне рішення має бути науково обґрунтованим, оптимальним, ефективним та результативним за будь-якого стану економічного середовища, в якому вони знаходяться.

Ми поділяємо думку А.А. Пересади стосовно того, що у системі управління інвестиціями оцінка ефективності інвестиційних проєктів являє собою один із найбільш відповідальних етапів. І оскільки однією за складних, але важливих фрорм інвестицій виступає реальний інвестиційний проєкт, який передбачає вкладення капіталу, а ідея будь-якого вкладення капіталу повинна обґрунтовуватися розрахунками корінного завдання, якою мірою майбутні доходи покривають нинішні (поточні витрати), тому важливим етапом інвестиційного процесу є проведення аналізу потенційних проєктів, який хоча і не залежить від інвестиційної політики держави чи регіону, але має великий вплив на прийняття майбутніх рішень [1].

Аналіз інвестиційних проєктів є складовою частиною процесу управління інвестиціями. Він дає інформаційну базу у вигляді проєкту як спеціально офрормленого інвестиційного плану або результатів проведеної експертизи проєкту для ухвалення рішення щодо початку його інвестування [2].

Для прийняття рішень щодо інвестування того чи іншого проєкту необхідною передумовою $€$ оцінка його економічної ефрективності. Така оцінка $€$ необхідною як для керівництва підприємства, яке здійснюватиме інвестиційний проєкт (для фрормування есрективного інвестиційного портфеля), так і для представлення її зовнішньому інвестору 3 метою довести йому доцільність вкладання коштів в окремий проєкт. Очевидно, що ймовірність прийняття помилкових інвестиційних рішень із боку керівництва підприємства залежатиме від якості оцінки економічної еоективності інвестиційних проєктів.

Для проведення фрінансового аналізу інвестиційних проєктів, у яких обґрунтовується й оцінюється ефрективність не лише використання інвестицій, а й усього інвестиційного процесу, важливими, на нашу думку, є показники оцінки економічної ефективності інвестицій.

Оцінка ефективності інвестицій є відповідальним етапом, який включає:

- орормування категорій інвестиційного процесу;

- показники, що характеризують зміст категорій;

- критерії, на основі яких проводиться порівняння [4].

Зазначимо, що згідно з визначенням Рахункової палати України, інвестиційні проєкти - це проєкти розвитку окремих галузей, секторів економіки, виробництв, фрінансування яких здійснюється на умовах самоокупності та обов'язкового внутрішнього співфінансування [8].

Ми погоджуємося 3 думкою В.П. Ніколаєва про те, що інвестиційний проєкт - це сукупність дій від виникнення ідеї, розроблення плану їі реалізації і до моменту досягнення мети. Лише проєкт як об'єкт управління за рахунок матеріалізації ідеї здатний із меншого зробити більше. Ні підприємство, ні регіон, ні галузь не $є$ іманентно прибутковими системами в умовах економіки, що змінюється [4].

В економічній літературі зустрічаються різні методи оцінки ефрективності інвестицій. Але, на нашу думку, найбільш прийнятним є підхід, за яким методи оцінки ефективності інвестицій можна поділити на дві групи:

- статистичні - базуються на облікових оцінках;

- динамічні - базуються на дисконтованих оцінках.

Статичні методи передбачають розрахунок показників на основі недисконтованих грошових потоків, тобто вони не враховують зміну вартості грошей у часі. Такі методи здебільшого використовувалися в умовах командно-адміністративної системи. А динамічні методи, навпаки, враховують зміну вартості грошей в часі і передбачають приведення вартостей усіх грошових потоків до одного й того ж самого періоду шляхом їх дисконтування чи компаундингу (нарощування). Тому саме динамічні методи набули широкого застосування у більшості країн світу, оскільки вони виявилися найбільш концептуально правильними та загальнопридатними для застосування у ринкових умовах.

До динамічних методів, оцінки ефрективності інвестиційних проєктів слід віднести такі основні методи, як:

- чиста теперішня вартість грошових потоків (ЧТВ);

- внутрішня ставка доходності (ВСД);

- індекс прибутковості проєкту (ІП);

- період окупності інвестицій (ПО).

Використання методу чистої теперішньої вартості передбачає визначення чистих грошових потоків за кожним періодом, визначення теперішньої вартості кожного чистого грошового потоку відповідного періоду, розрахунок чистої теперішньої вартості проєкту шляхом сумування всіх дисконтованих чистих грошових потоків [5].

Внутрішня ставка доходності - це таке значення норми дисконту, за якого теперішня вартість грошових потоків від реалізації проєкту дорівнює теперішній вартості інвестиційних витрат. Іншими словами, це значення норми дисконту, за якого чиста теперішня вартість проєкту дорівнює нулю. 
Індекс прибутковості показує, у скільки разів сума дисконтованих грошових потоків проєкту за весь період його реалізації перевищить теперішню вартість інвестиційних витрат.

Одним із найпростіших методів оцінки ефективності інвестицій, який досить часто використовується на практиці, є період окупності інвестицій. Він визначається як час, необхідний для того, щоб дисконтовані грошові потоки від інвестиційного проєкту зрівнялися 3 початковими інвестиціями в даний проєкт. Інакше кажучи, це час, коли чТВ проєкту змінює знак із від'ємного на додатний [6].

Важливо відзначити, що кожному 3 описаних вище методів оцінки ефективності інвестиційних проєктів притаманні певні недоліки. Наприклад, метод чистої теперішньої вартості не показує рівень прибутковості проєкту.

Своєю чергою, метод внутрішньої ставки доходності не враховує масштабу інвестицій. Окрім того, окремий проєкт може мати кілька значень внутрішньої ставки доходності, наприклад коли отримані від реалізації проєкту грошові потоки знову реінвестуються в даний проєкт.

На нашу думку, на сучасному етапі господарювання існує багато методів, які дають змогу здійснити аналіз ризику того чи іншого проєкту, проте більшість із них не дає відповіді на запитання щодо доцільності вкладання коштів в окремий проєкт, не дає змоги визначити економічну ефективність проєкту з урахуванням ступеня його ризикованості. Серед методів, які дають змогу визначити економічну еорективність інвестиційних проєктів з урахуванням ступеня їх ризику, на нашу думку, можна виділити два:

- метод еквівалента певності;

- метод поправки на ризик норми дисконтування.

Метод еквівалента певності передбачає коригування очікуваної вартості грошових потоків шляхом їх множення на коефіцієнт імовірності їх виникнення. Отримані таким чином грошові потоки називаються еквівалентами певності, що означає їх безпечну чи безризикову вартість [7].

В основі методу поправки на ризик норми дисконтування лежить додавання премії за ризик до безпечної (безризикової) ставки дисконту.

Одним із найновіших методів аналізу інвестиційних проєктів, на нашу думку, є квантово-економічний аналіз (KEA) [8].

Зазначимо, що КЕА - новітня методологія прогнозу, яка дає змогу передбачати і визначати ті проєкти і компанії, що є неефективними і не будуть мати успіху. КЕА не лише «обчислює» збиткові проєкти, а й дає змогу вибрати прийом, що може виправити положення, що створилося.

Відмінність КЕА від використовуваних у даний момент концепцій у тому, що ці методи засновані на аналізі документів бухгалтерського обліку, прогнозі показників, застосуванні до них аудиторського аналізу і розрахунку різних фрінансових коефріцієнтів. Однак фрінансовим розрахункам повинний передувати аналіз, що виявляє і відсіває апріорі неефективні та збиткові проєкти.

1. 3 погляду КЕА більшість проєктів збиткові саме тому, що їхні окремі складники не відповідають один одному. Наприклад, якийсь продукт $€$ кращим, але він не підходить для даного ринку. Або дана конкретна компанія не могла і не змогла позиціонувати даний продукт на даному ринку [8].

2. Отже, квантовий економічний аналіз розглядає класифрікацію етапів еволюції компаній, ринків і продуктів. Основна ідея концепції КЕА полягає у тому, що важливі не рівні еволюційного розвитку продукту, компанії і ринку самі по собі, а правильне сполучення цих рівнів. Уміння визначати дозволені і заборонені сполучення дало можливість створити інструментарій для інвесторів, менеджерів і маркетологів, що постійно розширюється і поповнюється [8].

Ми погоджуємося з думкою Н.І. Ільїна, І.Г. Лукманової, А.М. Немчина [8] про те, що успішне застосування КЕА неможливе без чіткого розуміння компанії. Для цього КЕА визначає компанію як інститут, створений із метою приносити максимальний прибуток власникам її акцій. Компанія залишається незмінною доти, доки не міняються власники акцій і розподіл пакетів між ними, або змінюються в результаті купівлі-продажу акції чи випуску компанією нового пакета.

За методикою КЕА, яка використовується Міжнародним інститутом техніко-економічного обґрунтування (MITEO), перспективність проєкту оцінюється в кілька етапів. На першому етапі оцінюються не тільки технічні переваги продукту, колектив і ресурси компанії, розміри ринку з його динамікою, а й визначають еволюційну стадію розвитку кожного із цих компонентів. На другому етапі наявне сполучення еволюційних рівнів розвитку продукту, компанії і ринку порівнюється з розробленою МITEO матрицею дозволених сполучень. Якщо комбінація, що вийшла, є дозволеною, проєкт може стати успішним. Якщо немає - проєкт нерентабельний у силу еволюційної несумісності ключових компонентів.

Хоча у світовій практиці основними підходами до аналізу інвестиційних проєктів є підходи, засновані на аналізі ризиків, однак за допомогою цих методів можна оцінити проєкти лише за можливими оцінками або фрінансовою звітністю. Новітній напрям аналізу інвестиційних проєктів дає змогу оцінити інвестиційний проєкт із погляду еволюції його складників і до кількісного аналізу визначити свідомо збиткові проєкти.

Міжнародний досвід оцінки ефективності інвестицій фрормує розуміння про різноплановість такої оцінки. Тобто кожна окремо взята країна проводить 
оцінку ефрективності інвестицій з урахування таких чинників, які актуальними, репрезентативними та потенційно корисними і небезпечними в умовах окремо взятої країни.

На нашу думку, класичні методи не можуть дати таку однозначну оцінку, а використання цих методів дає змогу не лише реалізовувати нові проєкти, а й доводити до логічного завершення раніше початі проєкти. Новітні підходи можуть також дати відповідь на питання про коректування допущених помилок на стадії реалізації проєкту.

Отже, вивчення зарубіжного досвіду [9], його узагальнення свідчать про наявність різноманітних підходів, моделей механізмів та інструментів стимулювання інвестиційних проєктів в інтересах держави. Серед них у контексті окремого проєкту слід виділити:

- вплив на визначення учасників проєкту, інвесторів, видів та фоом інвестицій;

- упровадження системи інвестиційних пільг;

- регулювання отримання прибутку учасниками проєкту;

- регулювання змін відносин власності;

- гарантії дотримання прав учасників на протязі проєкту.

На нашу думку, оцінку інвестиційного проєкту можна проводити в два етапи. На першому етапі характерною повинна бути оцінка інвестиційного проєкту в цілому й повинні оцінюватися суспільна значимість, ефрективність проєкту, комерційна есрективність проєкту та наявність державної підтримки реалізації проєкту. На другому етапі оцінку еорективності інвестиційного проєкту слід проводити з погляду:

1) бюджетної ефрективності проєкту, тобто необхідно провести оцінку фрінансових наслідків реалізації проєкту для державного і місцевого бюджетів (якщо проєкт потребує підтримки з боку місцевого або державного бюджету й є суспільно значимим);

2) регіональної ефективності проєкту (оцінку ефективності проєкту з позиції впливу на економіку регіону, якщо реалізація проєкту зачіпає інтереси регіону). Така оцінка повинна обґрунтовувати результативність проєкту з позиції вигід регіону й усіх прошарків суспільства. На нашу думку, така оцінка необхідна, оскільки інтереси інвестора не завжди збігаються із соціально-економічними інтересами регіону;

3) галузевої ефрективності проєкту. Таку оцінку слід проводити з погляду ефективності проєкту для певних галузей економіки [1].

Таким чином, визначення економічної ефективності інвестиційних проєктів є найважливішим і найскладнішим етапом до інвестиційних досліджень.

Від того, наскільки об'єктивно і всебічно здійснено цю оцінку, а отже, й правильно визначені подальші дії щодо того чи іншого проєкту, залежать терміни повернення інвестованих коштів. Своєю чергою, об'єктивність і всебічність забезпечують сучасні методи здійснення оцінки ефективності інвестиційних проєктів.

Висновки 3 проведеного дослідження. Отже, оцінка інвестиційних проєктів повинна ґрунтуватися на економічних, соціальних і екологічних умовах, вибраних і згрупованих 3 урахуванням цілей інвестування.

Розглянуті нами методи $€$ досить точними, оскільки, базуючись на простих розрахунках, вони дають змогу достатньо швидко здійснити оцінку економічної ефективності інвестиційних проєктів, їх можна використовувати під час вирішення таких питань, як прибутковість проєкту; визначити переваги різних варіантів розглянутого проєкту; з'ясувати, наскільки один проєкт ефективніший за інший.

У підсумку зазначимо, що методам оцінки економічної ефективності інвестицій приділено ще недостатньо уваги, хоча оцінка ефективності інвестиційного проєкту є ключовим питанням для інвестора. Під час оцінки інвестиційних проєктів окремими критеріями дуже важко порівняти проєкти та оцінити їх, тому різні критерії (економічні, фрінансові, соціальні, екологічні тощо) слід поєднувати в одне узагальнене значення. Разом із тим немає єдиної думки стосовно методології такої оцінки, що окреслює чітку перспективу подальших наукових пошуків та знаходження шляхів вирішення окреслених проблем.

\section{БІБЛІОГРАФІЧНИЙ СПИСОК:}

1. Пересада А.А. Інвестиційне кредитування : навчальний посібник. Київ : КНЕУ, 2002. 271 с.

2. Гераймович В.Л. Сучасні проблеми використання потенційних джерел інвестування. Науковий вісник Національного університету біоресурсів $i$ природокористування України. 2009. Вип. 142. Ч. 2. C. 14-19.

3. Законодавчі акти України. URL: www.liga.ua.

4. Ніколаєв В.П. Держава - фріскал чи інвестор? URL: http: //me.gov.ua (дата звернення: 11.04.2021).

5. Бєлоусова О.С. Проблеми розвитку сучасного інвестиційного ринку України. Інвестиції: практика та досвід. 2008. № 17. С. 2-5.

6. Мазур Г.О. Особливості державної інвестиційної політики України. Економіка ринкових відносин. 2011. № 2.

7. Коваленко Ю.М Інвестиційний менеджмент : навчальний посібник. Київ : КНЕУ, 2003. 134 с.

8. Ільїн Н.І. Керування проектами : підручник. Санкт-Петербург : Дватри, 1996. 610 с.

9. Доклад о мировых инвестициях, 2019 год. URL: http://www.un.org/ru/development/surveys/docs/ investments2019.pdf (дата звернення: 11.04.2021).

10. Аналітичний огляд банківської системи України за 2019 рік. URL: http://rurik.com.ua/documents/ research/bank_system_2019.pdf (дата звернення: 11.04.2021). 


\section{REFERENCES:}

1. Peresada A.A. (2010) Investytsiyne kredytuvannya [Investment lending]. Kyiv: KNEU. (in Ukrainian)

2. Geraimovych V.L. (2009) Suchasni problemy vykorystannya potentsiynykh dzherel investuvannya [Modern problems of using potential sources of investment]. Scientific herald of the Nat. University of Bioresources and Nature Management of Ukraine, vol. 142, part 2, pp. 14-19.

3. Legislative acts of Ukraine [Zakonodavchi akty Ukrayiny]. Available at: www.liga.ua (accessed 11 April 2021).

4. Nikolayev V.P. Derzhava - fiskal chy investor? [Is the state a fiscal or an investor?]. Available at: http://me.gov.ua (accessed 11 April 2021).

5. Belousova O.S. (2008) Problemy rozvytku suchasnoho investytsiynoho rynku Ukrayiny [Problems of development of the modern investment market of Ukraine]. Investments: practice and experience, no. 17.
6. Mazur H.O. (2011) Osoblyvosti derzhavnoyi investytsiynoyi polityky Ukrayiny [Peculiarities of the state investment policy of Ukraine]. Ekonomika rynkovykh vidnosyn, no. 2.

7. Kovalenko Y.M. (2003) Investytsiynyy menedzhment [Investment management]. Kyiv: KNEU. (in Ukrainian)

8. Ilyin N.I. (1996) Keruvannya proektamy [Project management]. Saint-Petersburg: Dvatri.

9. Doklad o mirovykh investitsiyakh (2019) World Investment Report, 2019. Available at: http://www.un.org/ ru/development/surveys/docs/investments2019.pdf (accessed 11 April 2021).

10. Analitychnyy ohlyad bankivskoyi systemy Ukrayiny za 2019 rik [Analytical review of the banking system of Ukraine for 2019]. Available at: http://rurik.com.ua/ documents/research/bank_system_2019.pdf (accessed 11 April 2021). 